\title{
Informal Politics of Integration: Christian Democratic and Transatlantic Networks in the Creation of ECSC core Europe
}

\author{
Wolfram KAISER and Brigitte LEUCHT
}

The historiography of the origins of the European Union (EU) has two main weaknesses. It is too state-centric and fails to conceptualise the embedded nature of ideas and their role in the creation and evolution of an integrated 'core Europe' after World War II. With the opening up of the archives of national governments and supranational institutions, research on the contemporary history of the EU has steadily moved on into the 1970s. We argue, however, that it is crucial to revisit the early postwar period to develop a more sophisticated notion and historical narrative of the formation of the supranational core Europe of the European Coal and Steel Community (ECSC) of six founding member-states. Sectoral integration in coal and steel did not lead directly to horizontal integration in the customs union of the European Economic Community (EEC). It created important path dependencies concerning some structural characteristics and policy solutions, however, especially the (self-) exclusion of Britain, the functional use of economic integration with long-term political as well as economic objectives, the introduction of the supranational principle and antitrust competition legislation.

Historians have predominately conceived of the formation of the ECSC as the result of interstate bargaining of 'national interests' by governments as cohesive, purposeful actors. ${ }^{1}$ Diplomatic historical accounts have been shaped by underlying 'realist' assumptions about the definition of such interests by autonomous foreign and European policy-making elites. In the case of France, such national interests included the control of Germany through integration and securing a dominant political leadership role for France, and in the case of Germany, regaining national sovereignty and achieving the integration of the newly created Federal Republic of Germany in Western Europe and the Atlantic Alliance on the basis of equality. The notion of American 'influence' in the historiography of transatlantic relations after 1945 similarly derives from the assumption of European state actors' interests in the involvement of the United States as 'ultimate arbiter'" in Western European politics. ${ }^{3}$ In this perspective, the United States primarily had powerful political, economic and military resources to secure for itself a dominant position in the

1. As an introduction to EU historiography see W. KAISER, From State to Society? The Historiography of European Integration, in: M. CINI, A.K. BOURNE (eds.), Palgrave Advances in European Union Studies, Palgrave, Basingstoke, 2006, pp.190-208.

2. G. LUNDESTAD, The United States and Western Europe since 1945. From 'Empire by Integration' to 'Transatlantic Drift', Oxford University Press, Oxford, 2003 [1998].

3. See for example K. SCHWABE, 'Ein Akt konstruktiver Staatskunst' - die USA und die Anfänge des Schuman-Plans, in: Idem. (ed.), Die Anfänge des Schuman Plans 1950/51, Nomos, Baden-Baden, 1988, pp.211-239. 
Atlantic Alliance. In contrast, Alan S. Milward has explained the origins of the ECSC with domestically derived, predominately economic interests of Western European states. ${ }^{4}$ He has emphasized their strategic goal of achieving trade and welfare gains in a larger internal market to sustain national welfare objectives and policies, as he argued in his most influential book, The European Rescue of the Nation-State. ${ }^{5}$ With its strong focus on bureaucratic policy-making, however, his conceptualisation of early European integration is almost equally state-centric and informed by 'rational choice' assumptions about national governments rationally defining interest-based policy objectives for interstate bargaining. Milward's recent decision to replace the term 'national interests' with 'strategies' merely marks a semantic, not substantive concession. ${ }^{6}$

None of this historical literature acknowledges the significance of ideas in early European integration as an independent variable. This is in part a reaction to the federalist hurrah historiography of early European integration in the tradition of Walter Lipgens, a committed federalist Christian democratic activist, ${ }^{7}$ and its underlying strong normative assumptions about the greater good of supranational institutionalisation. ${ }^{8}$ This literature never succeeded in establishing causal links between the ideas of the resistance and federalist movements in Europe and the actual European policies by governments after 1945. Similarly, much of the research centred around the role of Jean Monnet has overemphasized ideational motives and explained his influence with his role as leader of what appears like a tiny group of French officials who managed to stage a palace coup with the assistance of Foreign minister Robert Schuman as political figurehead. ${ }^{9}$ This literature, too, has largely failed to conceptualise how integration ideas advanced by Monnet and others were socially embedded and more importantly, how these actors actually succeeded in achieving their implementation in intergovernmental bargaining.

Against this background we propose that contemporary historians should look to social science research for approaches to studying the current EU which they can utilize in the first instance as heuristic devices for addressing these and other weaknesses of the under-conceptualised integration history. ${ }^{10} \mathrm{We}$ argue that the

4. A.S. MILWARD, The Reconstruction of Western Europe 1945-51, Methuen, London, 1984.

5. A.S. MILWARD, The European Rescue of the Nation-State, Routledge, London, 1992.

6. A.S. MILWARD, The Rise and Fall of a National Strategy 1945-1963, Frank Cass, London 2002, p.6.

7. On Lipgens see W. LOTH, Walter Lipgens (1925-1984), in: W. DUCHARDT et al. (eds.), Europa-Historiker. Ein biographisches Handbuch, vol.I, Vandenhoeck \& Ruprecht, 2006, pp.317-336; W. KAISER, “Überzeugter Katholik und CDU-Wähler”: Zur Historiographie der Integrationsgeschichte am Beispiel Walter Lipgens, in: Journal of European Integration History, 8(2002), pp.119-128.

8. W. LIPGENS, A History of European Integration, vol.I: 1945-1947, Clarendon Press, Oxford, 1982 [German edition 1977].

9. See for example F.J. FRANSEN, The Supranational Politics of Jean Monnet: Ideas and Origins of the European Community, Greenwood, Westport 2001, pp.87-113.

10. We also make this point strongly in W. KAISER, B. LEUCHT, M. RASMUSSEN (eds.), The History of the European Union. Origins of a Trans- and Supranational Polity 1950-72, Routledge, London, 2008. 
'policy network' approach has great potential for re-conceptualising the complex relations between different sets of actors and their policy ideas and preferences not only after core Europe institutionalisation, but also before the ECSC treaty came into force. ${ }^{11}$ In the social sciences, policy network analysis largely fed on the governance turn in public policy and international relations. ${ }^{12}$ As we have defined it elsewhere, this term denotes 'a shift from centralised 'government' by cohesive state institutions exercising their clearly defined powers in hierarchical forms of decision-making towards decentralised and informal forms of political communication and decision-making by sets of state and non-state actors in less hierarchically structured or even non-hierarchical relationships' ${ }^{13}$ In domestic political contexts social scientists observed from the 1980s onwards that the boundaries between state- and non-state actors became increasingly blurred and the exchange of resources between them - like expert knowledge and electoral support, for example - highly informal. ${ }^{14}$ In these fast changing circumstances of social communication and informal negotiation, policy networks linking different state and non-state actors play a central coordinating role in policy-making. Within the EU they do so within a system of 'multilevel governance' - a term intended to capture the specificity of the supranational polity as the interconnection of different layers of governance - the supranational, national and the regional and local - in a complex web of institutional and social relations. ${ }^{15}$

Most social scientists tend to believe that policy networks in or as governance is a recent phenomenon resulting from what they see as the 'hollowing-out' of the nation-state from the 1970 s onwards. ${ }^{16}$ We contend, however, that Western European states were less cohesive before the 1970s, that national governments were more fragmented and that they were often unable to agree and project cohesive 'interests' in intergovernmental bargaining, than the 'hollowing out' thesis about a decisive shift from 'government' to 'governance' after the oil crisis would make us believe. Indeed, we can relate in this regard to the shared assumption ${ }^{17}$ of authors like Lipgens and Milward that the Western European states were essentially weak after 1945 and that pro-integration elites sought to develop a

11. As an introduction to its application to the study of EU politics see A. WARLEIGH, Conceptual Combinations: Multilevel Governance and Policy Networks, in: M. CINI, A.K. BOURNE (eds.), Palgrave Advances ..., op.cit., pp.77-95.

12. R.A.W. RHODES, Understanding Governance: Ten Years On, in: Organization Studies, 28(2007), pp.1243-1264.

13. M. GEHLER, W. KAISER, B. LEUCHT, Networks in Informal European Governance: Diachronic Perspectives of the European Union as a Multi-level Polity, in: Idem., Netzwerke im europäischen Mehrebenensystem. Von 1945 bis zur Gegenwart / Networks in European Multilevel Governance. From 1945 to the Present, Böhlau, Vienna/Cologne/Weimar, 2008 (forthcoming).

14. See also K. HEARD-LAURÉOTE, Transnational Networks. Informal Governance in the European Political Space, in: W. KAISER, P. STARIE (eds.), Transnational European Union: Towards a Common Political Space, Routledge, London, 2005, pp.36-60.

15. For a recent overview see B. KOHLER-KOCH, B. RITTBERGER, Review Article: The 'Governance Turn' in EU Studies, in: Journal of Common Market Studies, 44(2006), pp.27-49.

16. See for example P. HIRST, Democracy and Governance, in: J. PIERRE (ed.), Debating Governance, Oxford University Press, Oxford, 2000, pp.13-25, here p.19. 
new common framework for 'governing'. This political choice was highly contested domestically, however, as was the policy content of the new integration framework. Political parties were internally divided. After Schuman announced the plan for coal and steel integration on 9 May 1950, French socialists argued over whether they should prioritise supranational integration over British participation, for example. At the same time, opponents among the German Christian democrats of the new chancellor Konrad Adenauer feared that his policy of Western integration would make unification impossible. Leading civil servants in foreign and economic ministries were divided, too, for example over the exclusion of Britain or - in the light of the European cartel tradition - the desirability of antitrust legislation. As Matthias Kipping and others have shown, ${ }^{18}$ business interests also could not agree on important features of market integration in coal and steel.

Against this background, we aim to analyse and ascertain how pro-integration political and administrative elites sought in this insecure policy environment to utilize mostly informal transnational networking to implement their ideas and preferences for the start of European integration. We do so drawing upon two case studies. We have chosen these case studies to test and bring out the influence of political and expert networks on agenda-setting and interstate negotiations in more narrowly continental European as well as geographically larger transatlantic settings. The first is the transnational political party network of Western European Christian democrats. At the time of the Schuman Plan, the Christian democrats alone formed national governments or were the largest party in coalition governments in all six ECSC founding member-states. Yet their political hegemony did not translate easily into government policy-making and intergovernmental bargaining due to internal divisions, coalition politics and domestic bureaucratic and business pressures. The second example is the transatlantic networks especially of civil servants and academic experts, not politicians, which included Monnet. Whereas the transnational networks of Christian democrats played a crucial role in agenda-setting up to the Schuman Plan including fundamental decisions like the combined supranationalism and exclusion of Britain from core Europe integration, the transatlantic network was more focussed on influencing the policy content of the interstate negotiations leading up to the signing of the ECSC treaty. In analysing these two networks we have to concentrate for the purposes of this article on essential information on their composition and in particular, their functions in the formation of core Europe. In conclusion, we briefly set out how the narrower

17. W. LOTH, Die Beiträge der Geschichtswissenschaft zur Deutung der Europäischen Integration, in: W. LOTH, W. WESSELS (eds.), Theorien europäischer Integration, Leske \& Budrich, Opladen, 2001, pp.87-106, here pp.91-96.

18. M. KIPPING, Zwischen Kartellen und Konkurrenz. Der Schuman-Plan und die Ursprünge der europäischen Einigung 1944-1952, Duncker \& Humblot, Berlin, 1996; F.M.B. LYNCH, France and the International Economy. From Vichy to the Treaty of Rome, Routledge, London, 1997; J. GILLINGHAM, Coal, Steel and the Rebirth of Europe, 1945-1955. The Germans and French from Ruhr Conflict to Economic Community, Cambridge University Press, Cambridge 1991. 
social science policy network approach may have to be adjusted for empirically oriented historical narratives of European integration, and what our research suggests for assessing the temporal dimension of networks in multilevel governance in historical perspective.

\section{Christian democratic network: Excluding the 'hereditary enemy' Britain}

Catholic people's parties originally formed transnational network-type contacts in interwar Europe. ${ }^{19}$ Whereas these loose contacts were dominated by left-Catholics with links to the Christian trade unions and the peace movement and a primary interest in national social policy reform, the new postwar network was largely controlled by liberal-conservative middle class Christian democrats. They organised their cooperation in the Nouvelles Equipes Internationales (NEI) created in 1947 which was transformed into the European Union of Christian Democrats (EUCD) in 1965, to be followed by the formation of the European People's Party (EPP) in 1976, which included only parties from European Communities (EC) states. At the same time, however, leading Christian democrats also met secretly in the so-called Geneva Circle from 1947 onwards. These high-level meetings were mediated by two private citizens, the Frenchman Victor Koutzine, who had close links with Georges Bidault, and the German Johann Jakob Kindt-Kieffer. They were attended by Bidault, Pierre-Henri Teitgen, Pierre Pflimlin, Konrad Adenauer, Josef Müller, Heinrich von Brentano and other leading politicians from the Mouvement Républicain Populaire (MRP) and the Christian Democratic Union / Christian Social Union (CDU/CSU) as well as other Western European parties. Their informal network-type collaboration extended to cooperation within the European Movement and the Assembly of the Council of Europe and included direct private contacts, for example between Adenauer and Schuman.

We have identified five main functions of this transnational Christian democratic network in the run-up to the Schuman Plan and during the subsequent interstate negotiations. ${ }^{20}$ The first is the lasting creation of social trust and political capital. The meetings in the informal private setting of the Geneva Circle with its free-ranging open discussions in particular helped to create normative-emotional bonds between the networked party elites. This was of crucial importance at a time when the general public especially in France was still highly sceptical, if not outright hostile to reconciliation with Germany and its full inclusion in new forms

19. W. KAISER, Von der Isolation im politischen Katholizismus in die (innere) Emigration. Transnationale Kooperation katholischer Volksparteien in Europa 1925-1933/38, in: J. MITTAG (ed.), Politische Parteien und europäische Integration. Entwicklung und Perspektiven transnationaler Parteienkooperation in Europa, Klartext, Essen, 2006, pp.215-228.

20. For a more detailed source-based analysis see W. KAISER, Christian Democracy and the Origins of European Union, Cambridge University Press, Cambridge, 2007, chapter 6. 
of institutionalised integration on the basis of equality as foreseen in the Schuman Plan. The Christian democrats could confidentially discuss issues like German rearmament and prepare policy decisions without fear of domestic political recriminations. Their party cooperation allowed them to communicate their congruent political beliefs and preferences, which made their governmental decision-making and diplomacy more mutually reliable. In hazardous political situations as after Schuman's visit to Bonn in January 1950 with the sharp public controversy about the anticipated signing of the Saar Conventions between France and the regional pro-French government in Saarbrücken, the Christian democrats could, and regularly did, activate their informal network contacts to smooth interstate relations.

Secondly, their transnational networking allowed those Christian democrats, who strongly supported the formation of a tightly integrated core Europe, to monopolize external party contacts and marginalize dissent within their own parties. Thus, Adenauer used informal networks to ensure that his views on Franco-German reconciliation and European integration also became known to MRP leaders who did not know him from interwar European politics like Schuman. Once he had secured the position as preferred partner of his French interlocutors by early 1948, he systematically excluded from transnational resources all sceptics of his European policy among disparate groups in his own party from liberal free traders like Ludwig Erhard, to left-Catholic nationalists like Jakob Kaiser and protestant conservatives like Friedrich Holzapfel. Adenauer, the CDU leader in the British zone of occupation, once invited Kaiser to the Geneva Circle during the Berlin blockade in March 1949, who predictably embarrassed himself with his enthusiastic assessment of the prospects of agreeing a deal with Stalin over unification. ${ }^{21}$ Adenauer also made certain that the re-founded left-Catholic Centre Party would not be allowed to partake in party cooperation. Within the MRP, which most nationalist Popular Republicans left in 1947 to form a rival Gaullist party, the minimal dissent against the emerging core Europe agenda was articulated by left-wing politicians like Leo Hamon, who like their German counterparts were not included in party cooperation. Hamon recollected later how the small anti-supranational Left in the MRP became more and more marginalized by what he experienced as the growing 'frenzied European fury'. ${ }^{22}$ The party network also helped socialise other leading Christian democrats into the emerging core Europe consensus. Thus, the Italian Prime minister Alcide De Gasperi, who was indirectly represented in the Geneva Circle by his confidant Paolo Emilio Taviani, initially adhered to a more Atlanticist foreign policy, but became converted to supranational integration. Bidault's strong support in the Geneva Circle for a core Europe without Britain in turn was a crucial precondition for his backing as Prime minister for the Schuman Plan in the decisive ministerial meeting, despite some misgivings about

21. Archiv für christlich-demokratische Politik (ACDP), 01-009-017, Geneva Circle, 8 March 1949.

22. Cited in J.-C. DELBREIL, LMRP et la construction européenne: résultats, interprétation et conclusion d'une enquête écrite et orale, in: S. BERSTEIN, J.-M. MAYEUR, P. MILZA (eds.), Le MRP et la construction européenne, Éditions Complexe, Paris, 1993, pp.309-363, here p.356. 
the foreseen degree of supranationalism. Informal networking also allowed the party elites to co-opt younger Christian democrats into their core Europe consensus like Leo Tindemans, Giulio Andreotti and Hans-August Lücker, who all took part in the NEI congress in Luxembourg in February 1948.

Thirdly, their transnational networking allowed leading Christian democrats to develop and agree common policy objectives. Embedded in similar ideological traditions as well as their Catholic confessional experience, they shared what Markus Jachtenfuchs has called a 'gesellschaftliches Deutungssystem'23, or social system for interpreting the world. On this basis, their informal cooperation between 1947 and 1950 allowed the Christian democrats to formulate two strong closely related preferences: achieving some degree of supranational integration and provoking the self-exclusion of Britain from new European projects. The protocols of the Geneva Circle meetings demonstrate how deep the antagonism was amongst most transnationally networked Catholic Christian democrats, not only towards the ruling Labour Party, but also Britain with its alien protestant political culture and as they saw it - its divide et impera foreign policy tradition precluding any long-term commitment to politically meaningful integration. In June 1949 Bidault concluded in the Geneva Circle that 'an English Europe [...] means no Europe at all'. ${ }^{24}$ Later, in January 1955, he and Teitgen over lunch even spoke of Britain as France's 'hereditary enemy' ${ }^{25}$ Some British middle-class Catholics initially had weak contacts with the NEI as an extension of Catholic cooperation in exile. ${ }^{26}$ Catholics played only a marginal role in the leadership of both larger parties, Labour and the Conservatives, however. Moreover, the vast majority of Catholic voters actually supported the Labour Party, which dominated the newly formed Socialist International. ${ }^{27}$

Their transnational cooperation - fourthly - allowed the Christian democrats to identify suitable political party and societal allies for constructing a sufficiently strong transnational coalition for their supranational core Europe without Britain. It was especially crucial to recruit the French socialists for the Schuman Plan. They were the most important 'Third Force' coalition partner, but had a strong affinity for cooperation with Britain. This political need in turn required a deeper understanding on the part of the German and Italian Christian democrats, who competed with socialist parties for government control, for the diplomacy of inviting the Labour Party to exclude itself, which it duly did with a 'Euro-sceptic'

23. M. JACHTENFUCHS, Die Konstruktion Europas. Verfassungsideen und institutionelle Entwicklung, Nomos, Baden-Baden, 2002, p.262.

24. ACDP, 01-009-017, Geneva Circle, 10 June 1949.

25. ACDP, 01-172-31, Geneva Circle, 31 January 1955, protocol Karl von Spreti.

26. See W. KAISER, Co-operation of European Catholic Politicians in Exile in Britain and the USA during the Second World War, in: Journal of Contemporary History, 35(2000), pp.439-465.

27. On the religious and confessional dimensions of the marginal societal support in Britain for some kind of 'united Europe' after 1945 see also P.M. COUPLAND, Britannia, Europa and Christendom. British Christians and European Integration, Palgrave, Basingstoke, 2006. 
policy manifesto and negative government decision, as a precondition for the support of the French socialists.

The fifth function was to help construct alliances with leading civil servants in ministries to prevent national administrations from throwing spanners in the wheels of interstate negotiations. While Monnet's integration concept was far too technocratic for the Christian democrats, and he was not close to them politically, they still worked with him and pro-integration civil servants in the Quai d'Orsay to marginalize dangerous internal dissent. After all, the French state administration was initially a stronghold of resistance to the supranational core Europe of integrated markets. The economic ministries were steeped in the tradition of protectionism and the Quai d'Orsay attached to Gaullist ideas of national greatness and power. Thus, René Massigli, the French ambassador to London, cautioned time and again against any German adventure without full British involvement. At times, the Christian democratic network also had to deal with deliberate leaks by hostile civil servants from within French ministries to prevent informal agreements as during one attempt in 1954 to sort out the contentious Saar issue. The Christian democrats also parachuted transnationally networked politicians into key positions as in the case of Taviani, who was appointed state secretary in the Palazzo Chigi and chief Italian ECSC negotiator, and von Brentano who was to chair the Constitutional Committee of the Ad hoc Assembly which drafted the European Political Community treaty in 1953.

All of these functions together greatly facilitated what political scientists with an interest in the role of individuals within policy networks, or more generally in EU politics, have called entrepreneurial leadership. ${ }^{28}$ Traditional concepts for explaining political leadership like Max Weber's notion of charisma, for example, have little relevance for the emerging multilevel European polity of intergovernmental bargaining and supranational institutionalisation. After the experience of Hitler and Mussolini, all Christian democratic leaders more or less ran - as Bidault once said about Schuman - on petrol of low octane rating. In 1950, moreover, they could neither rely on a permissive consensus on supranational integration nor expect guaranteed electoral benefits from the new policy. Despite American support for Schuman's policy of going it alone without Britain, the domestic and international policy-making environment remained highly insecure. In these adverse circumstances, their informal transnational party cooperation made their European policies mutually reliable and thus also helped reduce domestic political risks in a decisive way to facilitate bold and at times extremely controversial policy choices. Christian democratic politicians could largely exercise crucial political leadership in early European integration in and through networks.

28. See also, albeit in the context of intergovernmental conferences, D. BEACH, C. MAZZUCELLI, Introduction, in: idem. (eds.), Leadership in the Big Bangs of European Integration, Palgrave, Basingstoke, 2007, pp.1-21. For interesting conceptual insights see O.R. YOUNG, Political Leadership and Regime Formation: On the Development of Institutions in International Society, in: International Organization, 45(1991), pp.281-308. 


\section{Transatlantic networks: \\ Promoting a free market economy for an integrated Europe}

Informal transatlantic cooperation did not originate in 1945. However, the immediate post-World War II period gave rise to an especially increased density of contacts between American and European actors at a number of levels. Against this backdrop, two transatlantic networks of civil servants and academic experts with mutually relating actors developed at the Schuman Plan conference. ${ }^{29}$ A network attached to the American embassy in Paris and in part overlapping with the French delegation mainly comprised actors who cooperated in US and European administration agencies in the reconstruction of postwar Western Europe, including the French Planning Commission, the US High Commission for Germany and the European Co-operation Administration (ECA). Jean Monnet and US High commissioner John McCloy, whose friendship went back to the interwar period, facilitated the operation of what we call the 'US embassy working group' to expedite the successful conclusion of the interstate negotiations. Another informal network, the 'transatlantic university network', partly overlapped with the West German delegation and consisted of legal experts with an academic affiliation. This network shared important characteristics of what Peter M. Haas first called an 'epistemic community'. ${ }^{30}$ Crucial to its formation was the nomination of Walter Hallstein, a law professor at the University of Frankfurt, as head of the West German delegation.

We have identified five main functions of these transatlantic networks in the interstate negotiations on the Schuman Plan. The first is that informal transatlantic networks restricted the policy options available to the delegations and the designated conference working groups of experts. The US embassy working group in particular helped safeguard the compatibility of the ECSC treaty with the US government's policy preference for a supranational, integrated and competitive Western Europe. In accordance with the 'double containment' strategy vis-à-vis Germany and the Soviet Union the Truman administration promoted the integration of a democratic, capitalist and economically restored Germany into Western Europe to limit Soviet expansion. At the same time US postwar foreign policies including the Marshall Plan were informed by a rationale derived from the domestic tradition of US antitrust law, namely that competition provided the key to the dual goal of political stability and economic prosperity. Against this background, the US embassy working group reinforced restraining the policy options of the negotiating parties through assisting the constant flow of information

29. For a source-based description see B. LEUCHT, Transatlantische Politiknetzwerke: Kulturtransfer und Schuman-Plan 1950/51, in: Comparativ, 16(2006), pp.200-218.

30. P. HAAS, Introduction: Epistemic Communities and International Policy Coordination, in: International Organization, 1(1992), pp.1-35. For an early call to utilize the epistemic community and other policy network approaches cf. R. DWAN, Un outil puissant: les théories de l'élite et l'étude de la construction européenne, in: E. du RÉAU (ed.), Europe des élites? Europe des peuples? La construction de l'espace européen, 1945-1960, Sorbonne Nouvelle, Paris, 1998, pp.27-38. 
between these parties and US State Department and ECA officials and commenting policy papers and draft treaty versions. A case in point is a memorandum that emerged out of a discussion of two US network actors regarding the comprehensive working document that the French delegation presented shortly after the start of the interstate conference: Robert Bowie, a Harvard law professor with a background in antitrust law who as general counsel of the US High commissioner for Germany oversaw the de-cartelisation and de-concentration programme for the German heavy industries and William Tomlinson, the representative of the US Treasury in the US embassy in Paris and director of Financial and Trade Affairs for the ECA mission to France as well as financial advisor to the US ambassador to Paris David Bruce and a confidant of Monnet's. The memorandum examined the proposed institutional structure and criticised those aspects of the working document that appeared to foster cartels and restrictive practices. ${ }^{31}$ Later, it served as the basis for a checklist for the US government to evaluate the progress of the interstate negotiations. ${ }^{32}$

Informal transatlantic networks further contributed directly to the draft treaty, which constitutes a second function and perhaps the most apparent form of their influence on the evolution of the ECSC treaty. Crucially, they helped shape what became article 65 , banning agreements and practices hampering competition, and article 66, prohibiting market-dominating enterprises. ${ }^{33} \mathrm{~A}$ request to integrate specific antitrust provisions in the treaty was only expressed by Monnet in October 1950 following the start of the Korean War and the subsequent decision of the US government to rearm the Federal Republic. A first antitrust draft presented by the French delegation contained much more comprehensive antitrust provisions than an alternative proposal by the West German delegation and originated in consultations with the US embassy working group. In late November and early December 1950 this network became intimately involved in drafting proposals that then were formally submitted by the French delegation.

Thirdly, transatlantic networks mediated between different socio-economic, political and cultural contexts. In the making of the antitrust provisions, for example, the legal tradition of US antitrust law interacted with German ordoliberalism, an intellectual movement promoting an interdisciplinary approach to integrate economic policy and law that was first developed in the early 1930s to generate a response to the traumatic economic and political experiences of the Weimar Republic. Central to the mediation process in 1950-51 were the separate discussions on the West German de-concentration and the anti-cartel law for the

31. US National Archives and Records Administration (NARA), Washington DC, USA, Record Group (RG) 469, Special Representative in Europe, Office of the General Counsel, Subject Files 1948-53, Box 30, Memo Tomlinson to Stokes, 30 June 1950.

32. NARA, RG 59, Central Decimal Files 1950-54, 850.33/7-550, Bruce to Perkins, Check list of first draft of Schuman Proposal Working Document, 5 July 1950.

33. For a detailed analysis see B. LEUCHT, Transatlantic Policy Networks in the Creation of the First European Anti-Trust Law. Mediating Between American Anti-Trust and German Ordo-liberalism, in: W. KAISER, B. LEUCHT, M. RASMUSSEN (eds.), op.cit. 
Federal Republic which had become intimately tied to the interstate negotiations, not least through mutually relating actors. However, transatlantic networks owed their mediating function not only to the expertise of actors, but also to their biographical experiences as is evidenced by Hallstein who supplemented his longstanding academic interest in foreign legal systems with American socialisation and further in-depth study of US law while a prisoner of war in the US (1944-45) and an exchange professor at Georgetown University (1948-49). Even more Hallstein argued for cooperation between 'diverse legal traditions within the Euro-American cultural sphere' and highlighted the significance of American legal thought for the future of European law. ${ }^{34}$ In contrast German born Heinrich Kronstein, a law professor at Georgetown University, adopted a more pragmatic approach to mediation by advising US governmental agencies on antitrust policy and cooperating with the West German delegation to the interstate conference.

As a result of the predominant role of academic and other experts, informal transatlantic networks - fourthly - facilitated links to a wider circle of academics that could be co-opted for discussing the Schuman Plan. One pool of experts serving as a resource for the transatlantic university network emanated from an academic exchange programme between the University of Frankfurt and Georgetown University. Previously a participant in the programme, Hermann Mosler, as a legal expert of the West German delegation further invited the established Max-Planck Institute for Public and International Law in Heidelberg to assess the role of the court within the community's institutional system. ${ }^{35}$

The fifth function of transatlantic networks extends one specific function of the Christian democratic party network identified above, namely constructing transnational alliances to prevent national administrations and interest groups from impeding the interstate negotiations. Crucially this applied to sidelining those French officials and industrialists who subscribed to the French cartel tradition ${ }^{36}$ when integrating antitrust provisions into the ECSC treaty. At the same time the existence of transatlantic networks provided opportunities for actors whose preference for a competitive framework was marginalized within their respective domestic settings to transfer their policy goals from the national to the European level of the Schuman Plan conference.

Jointly these five functions highlight the complex policy-making processes at the interstate negotiations. Further, they help re-conceptualise the role of such transatlantic entrepreneurs as Monnet and McCloy who functioned as vital mediators between the US embassy working group and officials and politicians. Last, we argue that the involvement of experts in policy formation anticipated the

34. Bundesarchiv Koblenz, Nachlass Walter Hallstein (1266), 1620, Letter Hallstein to the Dean of the Faculty of Law, University of Chicago, 22 May 1945.

35. Politisches Archiv des Auswärtigen Amtes, Berlin, B 15 Sekretariat für Fragen des Schuman Plans, 54, Mosler to Karl Bilfinger, 16 September 1950.

36. On the divergent traditions and mentalities see B. LEUCHT, Tracing European Mentalities: Free Competition in Post-WW II-Europe, in: M.-T. BITSCH, W. LOTH, C. BARTHEL (eds.), Cultures politiques, opinions publiques et intégration européenne, Bruylant, Brussels, 2007, pp.337-353. 
increasing role of expert networks in devising EEC policies as is evidenced for example by the formulation of competition policy in Hans von der Groeben's Directorate General IV. ${ }^{37}$

\section{Conclusion}

Based on the two case studies of Christian democratic and transatlantic networks we argue that policy network analysis from political science can be fruitfully adopted for contemporary historical research on the EU, but with one main methodological caveat and after pragmatic conceptual adjustments. Methodologically, historical research has to rely predominately on written sources. These sources do not provide sufficient relevant data for either quantitative ${ }^{38}$ or formalized network analysis ${ }^{39}$ as two main options in the social sciences. Instead, historical research on networks in the integration process utilises a qualitative hermeneutical approach for interpreting sources and developing a sophisticated narrative of the informal politics of integration. At a more practical level, the informality of network exchanges makes their reconstruction more difficult than interstate negotiations that are formalized and more comprehensively documented in well preserved government sources. The resulting over-reliance on government sources by many contemporary historians has clearly solidified the conceptual state-centrism of EU historiography. For our case studies we were fortunately able to retrieve relevant primary sources in a multitude of archives including the protocols of the Geneva Circle, ${ }^{40}$ relevant policy papers and written correspondence in private papers, for example.

Conceptually, we propose a broader approach and somewhat more general definitions for historical research on transnational networks than policy network analysis of EU public policy-making. Firstly, we prefer to speak of political, not policy networks. The term political network denotes a set of actors engaged in communication and cooperation which is geared towards shaping the political organisation of social life, in this case in the emerging, highly institutionalised multilevel European polity. In our view such a broader definition has two main advantages. Firstly, it is not geared exclusively towards understanding policy-making in particular policy fields like the environment, for example, and

37. K. SEIDEL, DG IV and the Origins of a Supranational Competition Policy. Establishing an Economic Constitution for Europe, in: W. KAISER, B. LEUCHT, M. RASMUSSEN (eds.), op.cit.

38. See also F. PAPPI, C.H.C.A. HENNING, Policy Networks: More than a Metaphor?, in: Journal of Theoretical Politics, 10(1998), pp.553-575.

39. As an introduction see J. SCOTT, Social Network Analysis. A Handbook, $2^{\text {nd }}$ ed., Sage, London, 2000.

40. Excerpts of these protocols are accessible, together with other relevant sources, in M. GEHLER, W. KAISER (eds.), Transnationale Parteienkooperation der europäischen Christdemokraten. Dokumente 1945-1965 / Coopération transnationale des décmorates-chrétiens en Europe. Documents 1945-1965, K.G. Saur, Munich, 2004. 
measuring the direct policy impact of policy networks which is characteristic of policy network analysis. Transnational political networks have had other important functions, too. Contemporary historians may be as interested in studying internal processes of communication and socialisation within such networks from a more sociologically-informed perspective. At the same time, transnational networks of intellectuals after 1945 may have shaped public discourses and succeeded in ascribing dominant meaning to terms such as 'freedom' and 'Western world'. This in turn may have been a crucial precondition for culturally embedding European integration policies. Moreover, networks of political party elites clearly were not concerned with influencing only one policy field, but also with European constitution-building and supporting interstate relations on European issues. Secondly, the broader term political network also avoids an EU-centric perspective. As the example of the transatlantic networks shows, political networks have operated beyond the boundaries of core Europe and the current EU. They extended to other organisational contexts like the European Free Trade Association formed in 1959-60 and - especially in the first decade after World War II - the North Atlantic political space.

Secondly, we suggest to use the more traditional categories of state and non-state actors for characterizing the institutional identities of network actors. One often used political science distinction between public and private actors focuses on their objectives, that is whether they pursue 'public' (general) interests or 'private' (business) interests. Political scientists have shown, however, that networked business actors have often acted as private citizens and in the belief that their proposals - for example in the case of the European Round Table of Industrialists and the internal market programme in the early 1980s - were in the general European interest. ${ }^{41}$ With a distinction between public and private actors, moreover, political parties, although clearly non-state actors, would qualify as public actors just like governments. In our view such a definition not only effectively excludes from the research agenda all political networks that do not include private business actors; potentially, it could also result in normatively loaded debates over legitimate general public and egoistic private interests, which would not be helpful for developing a sophisticated historical narrative of EU politics in historical perspective. In contrast, our preferred definition crucially facilitates capturing the different and overlapping identities of actors. In the case of the Christian democrats, for example, leading politicians sometimes acted in their governmental state and sometimes in their non-state political party roles, without clearly distinguishing between their differentiated institutional identities and functional roles. In the case of the transatlantic networks, officials often acted as private citizens in social networks formed before they assumed official functions in national ministries or government agencies which also resulted in overlapping identities. We believe that this grey zone of blurred institutional identities and

41. See for example M.G. COWLES, Setting the Agenda for a New Europe: the ERT and EC 1992, in: Journal of Common Market Studies, 33(1995), pp.501-526. 
functional roles is especially crucial for understanding networks in early European integration.

With these methodological caveats and conceptual modifications we argue that in conjunction with 'institutionalist' approaches utilized in the article by Ann-Christina Knudsen and Morten Rasmussen in this issue, the theoretically informed empirical analysis of political networks has great heuristic potential for re-conceptualising the origins and evolution of the EU in historical perspective. Firstly, it can decisively help overcome the prevailing state-centrism of EU historiography in a new multi-actor perspective on EU politics and policy-making. Secondly, the study of networks allows us to capture the informality of political processes in the EU as a culturally diverse space, which is a crucial dimension of its identity as a supranational polity. Thirdly, it enables us to re-conceptualise in a radically different manner from traditional diplomatic history accounts, national EU policy-making as highly fragmented and influenced by transnationally networked political and administrative elites. Fourthly, the role of networks can help us understand better the exercise of political leadership under conditions of supranational integration, nationally and at the European level, as such networks provide state- and non-state actors with crucial resources for developing common agendas and pursuing their political goals - in our case studies, the formation of a supranational core Europe without Britain and a new legal framework for guaranteeing free competition in integrated European markets. Finally, the historical analysis of transnational political networks in conjunction with sociological institutional approaches, which emphasize the role of norms, values and ideas in policy-making, also offers an avenue for better understanding integration ideas as embedded in social networks. These networks strive to make such ideas hegemonic and to implement them in European constitutional designs and legislation. Such an approach avoids at the same time the naïve conceptualisation of ideational motivations for European policy-making as European idealism as in Walter Lipgens' early research and its sarcastic criticism as celebration of the so-called 'founding fathers' as European 'saints' by Alan S. Milward. $^{42}$

Once contemporary historians of the EU have begun to utilize the potential of the network concept and approach for understanding how multiple actors have related to each other within the emerging European multilevel polity and how their interaction has impacted on constitution-building, agenda-setting and decision-making, they could potentially also make a major interdisciplinary contribution to discussing networks in or as governance in a longer term temporal perspective. We hypothesize that networks played a crucial role in the evolution of institutional patterns and Community policies in the 1960s, especially in the two core fields of the Common Agricultural Policy and competition policy. They probably also influenced in important ways the development of new policy initiatives such as environmental protection and the internal market in the 1970s.

42. As in A.S. MILWARD, The Rescue ..., op.cit., chapter 6. 
These transnational political networks may have consisted chiefly of member state actors, the new supranational institutions and more traditional non-state actors like political parties as well as academic experts. It appears that the farmers' organisations at national and EEC level were the only major business interest that was fully engaged from the beginning in policy formulation at the EEC level. Nonetheless, member state actors were clearly neither as cohesive and consistent in their preference formation before the 1970s as much political science research appears to assume, just as they may be not nearly as ineffective after the alleged transformation from 'government' to 'governance' since then. We may well find that what was really novel in EC governance in the 1970s was the beginning sustained involvement of private business actors in EC politics driven by a fear of economic decline in comparison to the United States and Japan, and the activation of non-traditional new social movement societal actors, which was instigated and cultivated by the European Commission. These remain unanswered research questions for an exciting new research agenda within an innovative pluralistic EU historiography which should aim at greater interdisciplinary competence and cooperation. $^{43}$

43. For further suggestions for interdisciplinary collaboration between contemporary history and political science research on the EU see W. KAISER, History meets Politics: Overcoming Interdisciplinary Volapük in Research on the EU, in: Journal of European Public Policy, 15(2008), pp.300-313; Idem., Bringing People and Ideas Back in. Historical Research on the European Union, in: D. PHINNEMORE, A. WARLEIGH (eds.), Reflections on European Integration, Palgrave, Basingstoke, 2008 (forthcoming). 


\section{Der lange und mühsame Weg zu Europas Einheit}

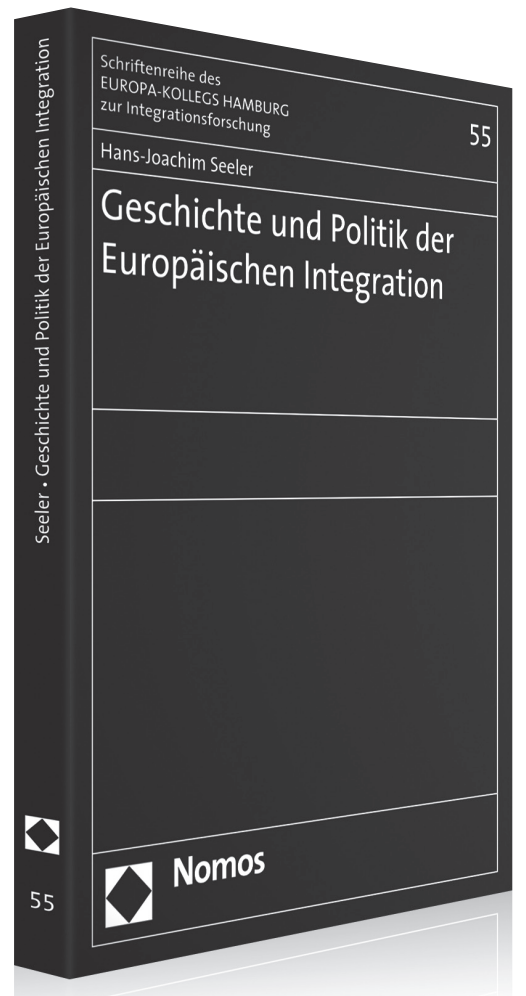

Das Werk bietet einen umfassenden Überblick über die Geschichte der Europäischen Union und der Europa-Idee.

Auf spannende Weise werden die einzelnen mühsamen Schritte auf dem Weg zur europäischen Einigung beschrieben: Von den „Römischen Verträgen“ über den „Vertrag von Maastricht“, die Gründung der Europäischen Union, die Vollendung des Binnenmarktes bis zum Beschluss zur Einführung des Euro. Im Jahre 2007 wurde der „Verfassungsvertrag" von Lissabon unterzeichnet, der die EU in ihrer Handlungsfähigkeit beträchtlich stärken wird.

Dieser freiwillige Zusammenschluss der europäischen Staaten sichert den dauerhaften Frieden zwischen ihnen und ist eine der größten politischen Leistungen Europas.

\section{Geschichte und Politik der Europäischen Integration}

Von Prof. Dr. Hans-Joachim Seeler 2008, 253 S., brosch., 54,- $€$, ISBN 978-3-8329-3208-4 (Schriftenreihe des EUROPAKOLLEGS HAMBURG zur Integrationsforschung, $B d$. 55) 


\title{
A European Political System in the Making 1958-1970: The Relevance of Emerging Committee Structures
}

\author{
Ann-Christina L. KNUDSEN and Morten RASMUSSEN
}

Most observers of Europe today would without much hesitation characterise the European Union (EU) as a political system, in spite of the fact that it lacks features of classical statehood such as a single government, a coherent foreign policy and a standing army. ${ }^{1}$ The notion of a (European) political system is a descriptive category, not a teleological prediction of the development of the European integration process. Hence, it makes no statements about the possible obsoleteness of the member states, a question that was at the core of the original debate between neofunctionalists and intergovernmentalists in the 1960s. ${ }^{2}$ Even today, the member states continue to wield a dominant influence on the European political system. For example, the EU still relies primarily on the member states for implementing legislation and administering coercion. At the same time, the European political system constrains member state power and has in a number of ways been transforming the European nation-state. Some scholars even argue that the post-war European integration project constitutes a new phase in the development of the system of European states. ${ }^{3}$ The European Union institutions regularly interact with citizens and social groups. Supranational legislation affects everyday lives in Europe in a wide range of areas; from labour market rules to commodity standards to food safety, and also influences the distribution of economic resources throughout the Union. Crucially, the development of the European political system has gone hand in hand with the emergence of significant elements of transnational European society, in which national political and economic elites have participated at multiple levels, thus greatly extending the political, economic, social and legal space available to the citizens. ${ }^{4}$

It is typically suggested that the European political system came into being in earnest around the early or mid 1980s. ${ }^{5}$ This has been identified through developments such as the '1992-programme', the Single European Act (SEA), the

1. A seminal article: S. HIX, The Study of the European Community: The Challenge to Comparative Politics, in: West European Politics, (1)1994, pp.1-30 was the first to propose the use of comparative politics analytical tools to treat the EU as a domestic arena. A more comprehensive account was later provided in S. HIX, The Political System of the European Union, Macmillan, London, 1999.

2. E.B. HAAS, The Uniting of Europe. Political, Social and Economic Forces 1950-1957, Stevens \& Sons Limited, London, 1958; L.N. LINDBERG, The Political Dynamics of European Integration, Stanford University Press, Stanford, California, 1963; S. HOFFMAN, Obstinate or Obsolete? The Fate of the Nation-State and the Case of Western Europe, in: Daedalus, (4)1966, pp.862-915.

3. S. BARTOLINI, Restructuring Europe. Center Formation, System Building, and Political Structuring between the Nation-State and the European Union, Oxford University Press, New York, 2005. See also, S. ROKKAN, P. FLORA, S. KUHLNE, D.D. URWIN, State Formation, Nation-Building, and Mass Politics in Europe: the Theory of Stein Rokkan, Oxford University Press, New York, 1999. 